\title{
Health policy and territorial politics: Disciplinary misunderstandings and directions for research
}

Scott L. Greer, University of Michigan slgreer@umich.edu

Contribution to Hepburn \& Detterbeck eds. Edward Elgar Handbook of Territorial Politics. Forthcoming, Edward Elgar.

8 April 2017

\begin{abstract}
:
The territorial politics of health is both underexploited by mainstream political scientists and the subject of a large and distinctive health policy literature that rarely connects with political science. This chapter first argues for the usefulness of health as a source of data for a more grounded and policy-focused territorial politics. It then summarizes the health policy approach to territorial politics, arguing that its empirical findings, more than its theories, can enrich political science on the topic. Subsequently, it turns to the findings of political scientists, highlighting the extent to which comparative welfare state literature is skeptical about federalism and could handle it much better, and the extent to which the literature about federalism and health is mostly nationally specific and overrepresents North American experiences. The last sections turn to some findings for comparative territorial politics from health policy studies, and some potential future directions for research.
\end{abstract}


Health policy is both an important and a frustrating topic for research in territorial politics. It is important because in many countries it is, along with education, one of the most important expenditure items for local and regional government. To write about states in Brazil or the U.S., regions in Italy or Spain, or devolved authorities in the UK without writing about health is to ignore a huge part of what they do and what their politicians must think about.

Furthermore, study of health and territorial politics could shed light on some of the knottiest problems in comparative politics. For territorial politics scholars, understanding health better would mean not just understanding one of the most important areas of public expenditure, but also would shed light on the kinds of variation that are common in decentralized states but obscured by a focus on legislation. Such variation happens, and matters, in organization, budgeting, staffing, and priorities within the public sector. Studying health also opens up new empirical approaches to problems in territorial politics such as the challenges of multi-level coordination and the diffusion of ideas and learning. For scholars in social policy and comparative political economy, understanding health care and policy better would free them from a tendency to focus on pensions and unemployment insurance as representations of the whole welfare state (e.g.(Esping-Andersen 1990, Hicks 1999) and come to grips with the complexity and complex knowledge politics that characterize the modern state (Jasanoff 2004a).

Health is also a frustrating topic, particularly for comparative research. Compared to other policy areas, part of the problem is that it is so difficult to characterize programs or understand causality. For example, we can calculate expenditure on unemployment or pensions by multiplying unemployment pay or pensions by the number of people legally entitled to them. In health, calculating need, desires, expenditure, or entitlement is very difficult. If everybody is essentially entitled to health care then variations in expenditure might be down to changing need, changing technologies, changing efficiency, discrimination, or budgeting decisions by politicians and managers. Entire careers are rightly dedicated to parsing out these factors, which means that quick policy analysis or comparison is very difficult. Furthermore, the health sector has a large set of articulate policy actors and analysts who generate both layers of complexity and their own analytic frameworks that compete with political scientists'.

The result is that research in territorial politics could and should derive a great deal of data and insight by examining the ways policymakers handle health, but faces a series of obstacles as basic as working out how much health care is being provided in two different jurisdictions. How has the challenge been handled?

For political scientists, the answer is probably: not frequently enough. For health policy researchers, the answer is probably: not well enough. This chapter starts with a quick discussion of health policy specialist literature, sketching their preoccupations and approaches, before turning to the insights into and use of health policy by territorial politics scholars. Concern about health in territorial politics is focused on health care, is mostly in dialogue with welfare state literature focused on 
the generosity and structure of welfare states, and does not always connect well with other literatures. Some of the best scholarship is concentrated in and on a the United States and Canada, which means that there is a great deal of scope for work outside those countries, or putting them into perspective. The final section focuses on some key and possibly internationally generalizable findings from those countries before a conclusion offers a critique and suggestion of new directions.

\section{Territorial politics in health policy}

A political scientist, encountering the literature on territorial politics and health for the first time, will notice that most people who publish on the topic come from health backgrounds, write in health journals, address health policy audiences, and tend to share some distinctive conceptual approaches. This is emblematic of the relationship between political science and health: a lack of interest in the topic among conventional political scientists, who leave the wealth of experience in the health sector largely untouched, juxtaposed with a distinctive health policy literature whose concerns and development are essentially separate and lead in some unexpected directions (for critiques of the health policy discussion of territorial politics, (Adolph, Greer, and Massard da Fonseca 2012, Greer and Massard da Fonseca 2015, Peckham et al. 2007).

First, the literature in health tends to focus on the concept of "decentralization" rather than federalism or territorial politics (Saltman, Bankauskaite, and Vrangbaek 2007). Decentralization, unlike federalism or territorial politics, implies an action taken by somebody central for an instrumental reason. This linguistic choice marks a decidedly technocratic style common in the literature, and reflects the fact that the bulk of literature on decentralization in health care comes out of global health research on the best means of delivering health services and development in low or middle income countries. In such literature, authors are often addressing governments, donors, finance ministries, or international financial institutions such as the World Bank, and accordingly deliver advice suited to those actors' interests. At its best, the result is advice for ministers and constitution-writers, most of it derived from the economics of fiscal federalism (Boadway and Shah 2009).

Second, the literature comes with a lack of interest in the distinctions between different kinds of political phenomena that political scientists might find surprising. Health policy writers recurrently cite Dennis Rondinelli, a public management researcher associated with the World Bank, for his taxonomy of decentralization (Rondinelli 1981, 1983), which was also adopted in a very influential 1990 World Bank paper (Mills et al. 1990). Rondinelli's taxonomy, which in its various published forms has thousands of citations, divides decentralization into four: deconcentration, which means moving central government work out of the capital; delegation, which means entrusting smaller units with centrally set responsibilities; devolution, which means transferring areas of responsibility to regional or local governments; and privatization, which means transfer of a responsibility to the private sector. The distinction between delegation and devolution seems to blur in theory and practice. In other words, one concept, 
decentralization, includes the establishment of the Scottish Parliament, the sale of British Telecom, and the decision to locate the UK's agency for driver and car registration in Wales. What they have in common is what interests the World Bank, rather than what interests scholars of politics: they shrink the central state. Not many political scientists have tried to use a framework that juxtaposes such different phenomena and when one did, the results were predictably abstract and banal (Lemieux 2001).

Even in health policy accounts that focus on territorial decentralization alone (devolution, in Rondinelli's taxonomy), there is a tendency to blur conventional distinctions political scientists make- between elected and unelected governments, between local governments and federal states, between single-purpose and general governments. Analyses of trends in decentralization can, as a result, incorporate recentralization of Scandinavian (local) health services, a reorganization of the French health system that, as David Jones points out, was actually centralizing, (Jones 2013) and devolution in the UK as similar processes. Such an analysis predictably produces somewhat confusing results (Saltman 2008).

An approach with these two characteristics of technocracy and limited discrimination among types is unlikely to contribute much to comparative politics. It is almost deliberately insensitive to political institutions and processes. It is a breath of fresh air relative to the economic modeling with which it frequently argues, but is conceptually underdeveloped as political science. It would bear some study by the scholars who examine the intertwined power relations and social construction in global health, development and "good governance" literatures (Andrews 2013, Ferguson 1990). Its high modernist tone (Bevir 2010), addressing a sort of Prince (or World Bank mission) who can engineer rules, societies, and incentives, is so unrealistic as to draw attention towards the political economy of such scholarship rather than its findings.

What the health policy literature does bring to political science is a fund of empirical studies on the implications of decentralization, as health policy scholars understand it. It is found in journals such as Health Policy and Planning as well as the large grey literature of reports and government publications typical of development and global health research. Properly interpreted, they offer a large fund of research results on topics such as local engagement, budgeting, management and health outcomes of changing authority structures, and corruption. There is very little relationship between this literature and the still larger literature on health inequalities of all kinds (Lynch 2017), including spatial health inequalities, but that would be an interesting direction for further research if we were able to match useful political variables to the increasingly detailed territorial health data available in rich countries.

There is also one clearly useful concept, developed by Bossert, which is the idea of "decision spaces" (Bossert 1998). Decision space is the "range of effective choice that is allowed by the central authorities... to be used by the local authorities" (p.1518). Bossert unfortunately goes on to adopt a principal-agent model in which local governments are the agents of central government. That is typical of the technocratic bent of this scholarship, but quite unrealistic if we are trying to characterize the relationship of California and the United States, let alone Sao Paulo 
and Brazil, let alone Quebec and Canada. The concept is nevertheless useful for its potential to produce a picture of decentralization with practical implications and precision beyond the best existing political science (Hooghe and Marks 2015) and has been put to good use, for example in international political economy (Koivusalo 2015).

\section{Health policy as comparative politics}

If the health policy research on territorial politics is voluminous, technocratic, and conceptually underdeveloped, the comparative political science research on the territorial politics of health is the reverse: small, politically focused and conceptual (with few exceptions, e.g. (Fierlbeck and Palley 2015a, Costa i Font and Greer 2013).

The main international literature in political science that does handle federalism and health is the comparative social policy and political economy literature. Federalism appears in this literature essentially as a veto point, an institutional barrier to welfare state growth or retrenchment. The most popular approach codes it as a component of an institutional "fragmentation" variable incorporating federalism, bicameralism, and other such institutional veto points. The origins of this concept were in Evelyn Huber and John Stephens' development of the concept of veto points as created by Ellen Immergut in her influential case studies of French, Swedish and Swiss health policy development (Huber, Ragin, and Stephens 1993, Immergut 1992) though it has close kinship with the work of other political scientists who focus on institutional impediments to policymaking (Stepan and Linz 2011, Gerring and Thacker 2008, Lijphart 1999). Huber and Stephens found that institutional fragmentation led to stingier welfare states across the board (Huber and Stephens 2001). When Castles and collaborators broke out federalism as a specific variable, albeit in a remarkably crude treatment, they found that it did correlate with less generous welfare states, though their research averaged data across the whole postwar period and stopped in the early 1990s (Castles 1999).

This macro-comparative approach has some serious limitations. It is possible to argue that Huber and Stephens are correlating an abstraction (a variable mixing the unlike, such as referenda and federalism) with an average (since in an area like health or education, the overall outcome might be the aggregate of regional decisions)(Greer, Elliott, and Oliver 2015). Snyder punned that such overuse of averages to characterize policy results in decentralized states is "mean-spirited thinking" (Snyder 2001). This problem means that it talks right past the smaller, and more Europe-focused, literature that focuses on the protagonism and actions of individual regions and which is generally more positive about the contribution of regional governments to welfare (McEwen and Moreno 2005). There are also serious mathematical problems in using regression techniques on an essentially cross-sectional analysis of a small number of countries (levels of decentralization rarely change, so the autocorrelation problem prevents effective use of time-series analysis). Modern statistical techniques effectively prevent designing a study similar to that of Castles and collaborator. The fact that this kind of research is small-N, autocorrelated and subject to omitted variable bias (every other variable associated with a country might matter), combined with publication bias, probably explains 
why there has been no replication or extension of this work since 1999.

Federalism might covary with less generous welfare states in comparative quantitative studies, but the mechanisms are unclear. Is it because of covariates of federalism such as bicameralism, or is it because of the countries that happen to be federal, such as the United States and Switzerland and also happen to be weak on other variables such as left parties that predict welfare state growth, or is it because federal states use their representation in central states to undermine welfare programs, or is it because governments within the federal state use, or are forced to use, their autonomy to fund variable and less generous health and welfare programs in a race to the bottom? When Castles and collaborators dug into the topic in an extensive comparative-historical inquiry, they found that history matters and that federal states establish welfare states through clever bypasses of their federal institutions (Obinger, Leibfried, and Castles 2005).

It is hard to go much further with the macro-comparative approach, for three reasons. First, one of the limitations in applying the broader comparative political economy literature to the topic of health is that health entitlements are intractable in comparative analysis compared to pensions and other payments. In most health systems there is no equivalent to the calculus of entitlement that governs pension or unemployment expenditure. As a result, the comparative politics of the welfare state has a strong tendency to focus on pensions, which are typically state-level, and pay less attention to the areas such as health and education that are more likely to involve decentralization and federalism. That is a convenience for scholars, but creates a highly unrepresentative picture of welfare states and welfare state politics.

The second reason is methodological. Despite the best efforts of statisticians, we only have about a dozen decentralized states in the OECD, and it is hard to do much with that N. If the United States and Switzerland drive international comparison towards a finding that federalism decreases welfare state expenditure but correlates with very expensive health systems, as they do, is that a problem with outliers or an accurate reflection of the world?

A third problem is conceptual. A concept like "fragmentation" mixes up different (if correlated) concepts. At a minimum, causal stories and data should distinguish between shared rule and self-rule if they are to make sense (Elazar 1987). Shared rule refers to the extent to which regional governments play a role in central state decision making. Self-rule is the extent of the autonomy of those governments to make their own decisions. In a federation with high self-rule and low shared rule, such as the UK or USA, it makes little sense to blame federalism for the decisions of the central state (Greer 2009). Far from being a hostage to states, the U.S. federal political system is paying less and less attention to them (Lowery, Gray, and Baumgartner 2010). In a federation with high shared-rule and limited self-rule, such as Germany or Austria, we can often regard federalism as primarily an electoral system for central elections.

This set of problems push us towards disaggregation (of country outcomes and of the meaning of "decentralization"), towards a focus on the configuration of causes rather the effect of some kind of "decentralization" or "federalism" variable, towards greater clarity about mechanisms and institutions such that territorial politics scholarship can provide and towards a qualitative comparative approach 
rather than a truncated quantitative approach that will always have a problem with degrees of freedom, data quality, and mechanisms (Greer 2018)

\section{Health politics as territorial politics: North American and comparative approaches}

There are two large, coherent, and interesting literatures on territorial politics and health. They are both North American, coming from Canada and the United States, respectively.

Canada is probably an international outlier for the consistency and depth of its political scientists' interest in both federalism and health policy. This presumably reflects decades of Canadian political interest in the topic (including several Royal Commissions and other inquiries into health, which focused debate and commissioned a great deal of research) and the fact that nearly all politics in Canada is territorial. The result is a large literature dating back decades and including some of the highlights of comparative research on territorial politics and health (Banting and Corbett 2002, Tuohy 1999, Maioni 1998, Lazar et al. 2013)(Fierlbeck forthcoming). This scholarly effort includes serious comparisons of provinces as complex political systems (Dunn 2006), a Canadian genre with few equivalents elsewhere, and a project to publish complete reports on provincial health systems modeled on the European Observatory on Health Systems and Policies' series of country reports (Marchildon and O'Fee 2007, Marchildon and Torgerson 2013).

The United States literature is quite different (Okma and Marmor 2015). Territorial politics and health, as a topic, plays to the strengths of American political science with its interesting state-federal interactions, wealth of documentation, state variation, complex intergovernmental games, and basically constant setting of the US federal system. One result is both a thriving health politics literature on state and federal programs, found especially in the Journal of Health Politics, Policy and Law and Publius. It includes work that takes states seriously as health policy actors (Fox 2010, Hwang, Sharfstein, and Koller 2015), work on specific states and their relationship with federal programs such as Medicaid (Holahan, Weil, and Wiener 2003, Thompson 2012), work on the impact of states on healthcare access (Moynihan, Herd, and Ribgy 2013) and inequality (Kelly and Witko 2012), work on the functional specialization of states (Anton 1997, Greer and Jacobson 2010), and a bit of work, ripe for extension and testing, that applies general themes in American political development, such as the role of federalism in institutionalizing racism, in the context of health policy (Lieberman and Lapinski 2001). Health policy researchers are probably among the American public policy researchers most interested in states, perhaps because the complexity and expense of U.S. health care means that relatively small variations in outcomes can have interesting politics and big consequences.

A second result is writing that uses health cases with theories about issues that interest students of the U.S. political system in general, such as interstate variation, policy learning, and intergovernmental relations, well reviewed in a slightly dated article by Miller (Miller 2004) as well as (Gray, Lowery, and Benz 2013, Weissert and Weissert 2012). These studies use health case studies and 
broader theories of the American political system to understand events. Journals such as State Politics and Policy Quarterly and public administration journals regularly publish articles on states that use health issues as examples.

The passage of the Affordable Care Act, also known as Obamacare, has created a very high-stakes and interesting case study in federalism in US health care. It has been exploited by a number of researchers (Jones, Bradley, and Oberlander 2013, Jones, Singer, and Ayanian 2014, Jacobs and Callaghan 2013, McCann 2015, Martin, Strach, and Schackman 2013, Béland, Rocco, and Waddan 2014, 2016).

Both North American schools might be envied by those working in lessstudied systems, but along with their characteristic advantages, such as the Canadian focus on the relationship between constitutional and health politics or interest in the politics of individual provinces, come characteristic disadvantages, such as the lack of interest among U.S. scholars in exploring the generalizability of many of their ideas. Both literatures might usefully be mined for examples of possible approaches to federalism as much or more than as sources of theory.

\section{Components of a comparative territorial politics of health}

There is not much principled reason why the comparative territorial politics of health should not be, essentially, a subfield of comparative territorial politics, comparative public policy, or comparative political economy in general. Health might be more complex than education or more expensive than cultural policy, but it is ultimately one more area of public policy, and the generalists in charge of government must treat it as such. What research in health, or any other big public policy, should do is draw our attention to a number of issues that are not always handled well in comparative territorial politics or comparative political economy.

First, it is impossible to understand territorial politics without understanding the most expensive and prominent programs in a given jurisdiction. Most governments cannot escape spending a huge amount of money on health or dealing with a great deal of credit and blame. Most citizens' experience of, for example, Scottish devolution is experience of the NHS Scotland and the education system, and that means Scottish politicians do not have much leeway to handle it badly (Greer et al forthcoming). Even in systems with little formal regional role in health, such as Austria or Germany, there is often a substantial amount of regional expenditure, regional administration, and blame or credit for politicians, in health (Mätzke and Stöger 2015, Mätzke 2013). Likewise, regulating any health system is a major challenge and an opportunity for students of regulation.

Second, understanding territorial politics means understanding the politics of managing large public sector organizations such as health systems. There is a tendency in comparative territorial politics to let politicians set the agenda, with arguments about competencies, symbolic politics, shifting power relations (e.g. with the EU), and high profile negotiations dominating political research as much as political journalism. The problem with such an approach is that we cannot reduce the agendas of governments to issues connected with authority migration; they also manage, and cope with the interest groups, of big public sectors. Starting with big expenditure items and management challenges such as health or other public 
policies helps us avoid an excessive focus on policy areas whose symbolism exceeds their actual importance.

Third and consequently, health policy directs us to be specific where much comparative literature is vague. Above all this means money, where academic literature is often remarkably hazy despite its importance for wielding power or getting things done (e.g.(Loughlin, Hendriks, and Lidström 2011). Even when the public sector itself is hazy about data, whether it is the UK's steadily diminishing supply of comparable data (Greer 2014, Bevan et al. 2014) or the outright obfuscation about Spanish intergovernmental fiscal transfers (Gray 2014), it is interesting to know which kinds of facts elites prefer to hide or not collect (Laible forthcoming). In the current climate of austerity, such research is necessary if we are to get an understanding of whether austerity and economic contraction actually do lead to re-centralization.

With these reasons in mind, what does the fragmented literature on territorial politics and health seem to suggest?

Some points are relatively basic. First, the formal organization of health care matters. NHS (national health service also known as Beveridge) systems, in which the government directly finances and frequently owns health systems, often decentralize much health care responsibility. These countries include Australia, Canada, Italy, Spain and the UK, and to some extent much of Latin America. In these systems, the government directly finances and manages health care, and the amounts of money, credit, and blame are accordingly large. By contrast, in social health insurance systems (SHI, also known as Bismarckian systems), there is a great deal of resistance to formal recognition of the role of territory or local governments. The German constitutional court has gone so far as to say there is no role for territory in social insurance (Mätzke 2013). That does not mean that Bismarckian federal states such as Germany and Austria lack a role for regional governments; it just means that their often considerable expenditure does not come with as much power or legitimacy as an actor (Mätzke and Stöger 2015). Such countries include Austria, Belgium, and Germany. Formal federal status, generally not worth worrying about, is almost entirely wiped out by the structure of the health service (e.g. the role of government) and the specific role, powers, and financing of regional governments (Costa-i-Font and Greer 2013).

Then, there are some points we can draw from the comparative health care federalism literature, as well as the country-specific literature read with a comparative, generalizable, eye. Administration matters a great deal. Much of what regional governments do in health is administer, and regional administration, measured on the level of specific issues (mental health, cancer, public health) is where the territorial politics of health actually produces interesting results for patients and voters. Further, examining the origins of policies addressing topics such as cancer care or health inequalities will generally reveal more territorial politics than can be seen when we focus only on regional politicians; regional medical elites, political entrepreneurs and others start to matter. Greater attention to administrative variation among different jurisdictions within ostensibly similar systems might be very rewarding. 
The sheer cost of health also means that health systems, regardless of the specific financing system, are a permanent problem to finance ministers. In decentralized NHS systems, in particular, they are a laboratory to examine what effective central control might look like (better than education, which often has substantial local political authority). What broadly emerges is that money is more powerful than law. Decentralized countries are littered with efforts to set standards and compare outcomes. Not only is comparative data something politicians tend to resist the effects are unpredictable and quality often debated. As for laws, even the most effective, such as the Canada Health Act, probably gain most of their force from the political consequences of disobeying them rather than the likelihood of the federal government enforcing them in court. There are cases of patients litigating a right to health, as is happening in Brazil right now, but in general laws are guidelines for negotiations and money is what actually matters. Thus, for example, the Brazilian federal government was able to create a welfare state through conditional grants to regional and local governments despite a federal constitution that should have blocked it (Arretche 2013, Arretche and Massard da Fonseca 2014). Equally, various Spanish central government efforts to shape health care quality were generally ineffective in the good times, but enforcement of austerity since 2010 in Spain has constrained regional governments while leaving them with much of the blame for the resulting cutbacks. In general, the experience of health suggests that money, especially conditional grants, is more important than law, and characterizing law accurately means viewing it as part of a debate rather than an agreement.

Health policy also suggests that local media are very important. As traditional print and broadcast media decline and new media rise, the media are also hard to characterize. The health sector is a "dripping roast for the local media," as a health manager in Scotland once said to me, and the result is that if there is a local media there is an erratic but energetic source of accountability and pressure on ministers. Given that most patients and voters have very little idea of the quality of their personal health care, let alone their health system, the presence, absence, and behavior of the media is important. Not least, the media shapes the likelihood that a decentralized health system reaps the benefits of accountability and public engagement that the more optimistic theorists of decentralization like to impute (Costa-i-Font and Greer 2013, Palley and Fierlbeck 2015).

Finally, health care politics reminds us that parties are not the only networks. The role of political parties in tying together disparate politicians, aligning their interests, and sorting out preferences, is well established across political science including territorial politics. But the role of parties in formal politics should not blind us to the role of similar kinds of networks in less formal politics. Medical organization and practice is often shaped by guidelines whose production is just as political, and subject to legal, interest group, and political influence as any law. Pressure to improve the credentials of nurses, save premature infants at 23 weeks, or adopt certain health education policies are likely to both move outside formal politics and manifest themselves via formal, often regional, decisions whose origins will not be clear if we confine ourselves to the study of formal politics. The most powerful kinds of political engagement often come in the form of ostensibly 
apolitical science (Jasanoff 2004b). It might be that local and regional governments are especially good places for such politico-scientific action to take place (Fox 2013). The implication is that if political scientists ignore the politics of medicine and public health, they will not just fail to understand what politicians and officials do most of the day; they will also mis-characterize the motivations and actions of many of the players they do study.

\section{Conclusion: Possible directions}

Fierlbeck and Palley write that the "study of health care federalism is underrepresented in the field of comparative political science...there are very few systematic studies which focus on the dynamics between federal and regional governments (and between regional governments) across a number of federal states" (Fierlbeck and Palley 2015b)(p1). So far, the people trying to address this gap are mostly political scientists solidly grounded in health knowledge, and the findings are cumulating slowly. There has been little reciprocal attention from more general political science, since public policy in general has not been seen as an easy way to develop knowledge about formal politics and institutions. The best dialogues are in the different North American political science worlds, but their generalizability, as against inspirational value, remains to be seen.

One basic direction is to ask what the study of health can do for comparative territorial politics. Here, the question is what established topics in territorial politics might benefit from research in health policy. One topic in comparative territorial politics that has been frustrating but might be well addressed with additional research in health is the study of how policies are adopted in different jurisdictions, whether we call it policy transfer, learning, diffusion, or something else. This has been a frustrating literature in which political scientists have made at best slow theoretical progress (Boushey 2010). Study of how ideas appear in different regions might be a way to trace the relative influence of government to government learning, professional and political networks that carry ideas, and more functionalist arguments- in other words, we could pick up where Baumgartner and Jones left off in their studies of interlinked agendas within the U.S. federal system (Baumgartner and Jones 1993, Lowery, Gray, and Baumgartner 2010, Shipan and Volden 2008).

A second topic where health data might be particularly useful would emerge if we could couple more detailed budget and eligibility data in order to understand the response of different territorial political systems to issues such as ageing societies or "new social risks" (Greer 2018, Greer, Elliott, and Oliver 2015). How does the allocation of power in different systems, such as the degree of regional selfrule and shared rule, produce different kinds of social policy results and empower different interests? How do the designs of health systems reflect, or fail to reflect, the neat functionalist models associated with the economics of fiscal federalism? One study (Adolph, Greer, and Massard da Fonseca 2012) found that the answer was: surprisingly well. That, in turn, raises the questions about why such isomorphism might exist. Could economists, with their functionalist approach, be right about the evolution of federations? 
Another way to think about future research directions is to ask what the study of comparative territorial politics can do for research in health policy (Greer and Massard da Fonseca 2015). This question is, in a sense, easy because there is so much excluded from the technocratic and strangely apolitical global health policy literature on decentralization. There are some basic points that are easily made and need to be made. For example, decentralization or federalism is often so well established as to not be debatable, or is a condition for keeping a country together. Contemplating the advisability of federalism in Belgium or Canada is beside the point. Likewise, distinguishing between elected and unelected governments is absolutely basic to political science, but is a distinction not reliably made in health policy literature. In short, there is an enormous opportunity for arbitrage between political science and health policy studies.

Then there are simply unexplored areas of inquiry. Almost the entire discussion above has focused, along with the literature, on health care. The broader area of public health- the field of prevention of disease- receives almost no attention from any political scientist (for a few laudable exceptions, (Lillvis, Kirkland, and Frick 2014, Kurzer 2012). This means that political science foregoes a fascinating policy area, one quite unlike the high spending area of health care, with especially interesting intergovernmental divisions of labor (Adolph, Greer, and Massard da Fonseca 2012). One almost entirely unexplored area, which might the most comparable across the diverse federations of the world, is communicable disease control (Greer and Mätzke 2012, Greer 2015). Equally, the comparative study of how different governments try to shape their populations' health and behavior, including public health interventions, is neglected. Tobacco control, for example, is almost impossible to understand without considering the interplay of local and regional action and international networks (Asare, Cairney, and Studlar 2009, Jarman 2014, Duina and Kurzer 2004, Shipan and Volden 2006, 2008).

Political scientists' understanding of health care, which tends to be most interested in financing, legislation, and regulation, also leaves aside at least one great and largely unexplored hypothesis. That is historian Daniel Fox's concept of "hierarchical regionalism" as a theme of UK and US health policy in the twentieth century (Fox 1986, Webster 1990). Fox argued that comparative and historical literature focused on the question of coverage entitlements missed the fact that health care leaders, particularly doctors, were more likely to be engaged in furious contests about the organization of health care- in particular, lining up for and against the hierarchical regionalist idea that health care should be organized regionally around major teaching and academic research facilities. This thesis has not redirected research away from the politics of health care entitlements, but deserves exploration as a factor in understanding the thinking of health care policymakers about regionalism of all sorts. Political scientists like to discuss health care access and finance, but are often deaf to the actual politics that matter to key people in the game. As a result, there is tremendous scope for research into the interaction between health politics and territorial politics that takes the complexity of health politics seriously.

Health is expensive and deeply interesting to citizens and the press. That makes it a core preoccupation of any politicians with health policy responsibilities. 
But it has not received the attention that it deserves from political scientists who strive to understand territorial politics. Avoiding the expense, policy intricacies, lobbying, puzzling issues and management challenges of health policy is a luxury that many politicians do not get, and political scientists should therefore not indulge themselves either if they hope to understand the rise and fall of governments, policies, and political careers.

Adolph, Christopher, Scott L Greer, and Elize Massard da Fonseca. 2012. "Allocation of authority in European health policy." Soc Sci Med 75 (9):1595-603. doi: 10.1016/j.socscimed.2012.05.041.

Andrews, Matt. 2013. The limits of institutional reform in development: Cambridge University Press.

Anton, Thomas J. 1997. "New Federalism and Intergovernmental Fiscal Relationships: The Implications for Health Policy." Journal of Health Politics, Policy and Law 22 (3):691-720. doi: 10.1215/03616878-22-3-691.

Arretche, Marta. 2013. "Constraining or Demos-Enabling Federalism? Political Institutions and Policy Change in Brazil." Journal of Politics in Latin America 5 (2):133-150.

Arretche, Marta, and Elize Massard da Fonseca. 2014. "Health System Decentralization in Brazil." In Federalism and Health Decentralization, edited by G. Marchildon and T. Bossert, \#\#\#-\#\#\#. \#\#\#: Forum of Federations.

Asare, Bossman, Paul Cairney, and Donley T Studlar. 2009. "Federalism and Multilevel Governance in Tobacco Policy: the European Union, the United Kingdom, and Devolved UK Institutions." Journal of Public Policy 29 (01):79102.

Banting, Keith G, and Stan Corbett. 2002. Health Policy and Federalism: A Comparative Perspective. Montreal and Kingston: Institute of Intergovernmental Relations/ McGill-Queens University Press.

Baumgartner, Frank R, and Bryan D Jones. 1993. Agendas and Instability in American Politics. Chicago: University of Chicago Press.

Béland, Daniel, Philip Rocco, and Alex Waddan. 2014. "Implementing health care reform in the United States: Intergovernmental politics and the dilemmas of institutional design." Health Policy. doi: 10.1016/j.healthpol.2014.01.010.

Béland, Daniel, Philip Rocco, and Alex Waddan. 2016. Obamacare Wars: Federalism, State Politics and the Affordable Care Act. Lawrence, KS: University Press of Kansas.

Bevan, Gwyn, Marina Karanikolos, Josephine Exley, Ellen Nolte, Sheelah Connolly, and Nicholas Mays. 2014. The four health systems of the United Kingdom: how do they compare? London: Health Foundation and Nuffield Trust.

Bevir, Mark. 2010. Democratic governance. Princeton, N.J.: Princeton University Press. 
Boadway, Robin, and Anwar Shah. 2009. Fiscal Federalism: Principles and Practice of Multi-Order Governance. Cambridge: Cambridge University Press.

Bossert, Thomas. 1998. "Analyzing the Decentralization of Health Systems in Developing Countries: Decision Space, Innovation and Performance." Social Science and Medicine 47 (10):1513-1527.

Boushey, Graeme. 2010. Policy Diffusion Dynamics in America. Cambridge: Cambridge Univ Press.

Castles, Francis G. 1999. "Decentralization and the post-war political economy." European Journal of Political Research 36 (1):27-53.

Costa i Font, Joan, and Scott L Greer, eds. 2013. Federalism and Decentralization in European Health and Social Care. Basingstoke: Palgrave Macmillan.

Costa-i-Font, Joan, and Scott L Greer. 2013. "Territory and Health: Perspectives from Economics and Political Science." In Federalism and Decentralization in European Health and Social Care, edited by Joan Costa-i-Font and Scott L Greer, 13-44. Basingstoke: Palgrave Macmillan.

Duina, F., and P. Kurzer. 2004. "Smoke in your eyes: the struggle over tobacco control in the European Union." Journal of European Public Policy 11 (1):5777.

Dunn, C. 2006. Provinces: Canadian Provincial Politics, Second Edition: University of Toronto Press, Higher Education Division.

Elazar, Daniel. 1987. Exploring Federalism. Tuscaloosa: University of Alabama press. Esping-Andersen, Gosta. 1990. The Three Worlds of Welfare Capitalism. Princeton, NJ: Princeton University Press.

Ferguson, James. 1990. The anti-politics machine: development, depoliticization, and bureaucratic power in Lesotho. Cambridge: Cambridge University Press.

Fierlbeck, Katherine, and Howard A Palley, eds. 2015a. Comparative Health Care Federalism. Farnham: Ashgate.

Fierlbeck, Katherine, and Howard A. Palley. 2015b. "Comparative Policy Analysis, Health Care, and Federal Systems." In Comparative Health Care Federalism, edited by Katherine Fierlbeck and Howard A. Palley, 1-15. Farnham: Ashgate.

Fox, Daniel M. 1986. Health Politics, Health Policies: The British and American Experience, 1911-1965. Princeton, NJ: Princeton University Press.

Fox, Daniel M. 2010. The convergence of science and governance : research, health policy, and American states. Berkeley: University of California Press.

Fox, Daniel M. 2013. "Health inequality and governance in Scotland since 2007." Public Health 127 (6):503-513. doi: 10.1016/j.puhe.2013.04.019.

Gerring, John, and Strom C Thacker. 2008. A Centripetal Theory of Democratic Governance. Cambridge: Cambridge University Press.

Gray, Caroline. 2014. "Smoke and mirrors: How regional finances complicate Spanish-Catalan relations." International Journal of Iberian Studies 27 (1):2142.

Gray, V., D. Lowery, and J.K. Benz. 2013. Interest Groups and Health Care Reform Across the United States: Georgetown University Press.

Greer, S L, and M. Mätzke. 2012. "Bacteria without Borders: Communicable Disease Politics in Europe." Journal of Health Politics, Policy and Law 37 (6):815- 914. 
Greer, Scott L. 2009. "How does decentralisation affect the welfare state?" Journal of Social Policy 39 (2):1-21.

Greer, Scott L. 2014. "Devolution and health: data and democracy." BMJ 348.

Greer, Scott L. 2015. "Intergovernmental governance for health: Federalism, decentralization and communicable diseases." In Strengthening health system governance: better policies, stronger performance, edited by Scott Greer, Matthias Wismar and Josep Figueras. Brussels/Maidenhead: European Observatory on Health Systems and Policies/ Open University Press.

Greer, Scott L, and Peter D Jacobson. 2010. "Health Policy and Federalism." Journal of Health Politics, Policy and Law 35 (2):203-226.

Greer, Scott L., ed. 2018. Federalism in good times and bad. Ann Arbor.

Greer, Scott L., Heather Elliott, and Rebecca Oliver. 2015. "Differences That Matter: Overcoming Methodological Nationalism in Comparative Social Policy Research." Journal of Comparative Policy Analysis: Research and Practice 17 (4):408-429. doi: 10.1080/13876988.2015.1060713.

Greer, Scott L., and Elize Massard da Fonseca. 2015. "Decentralization and Health Systems Governance." In Palgrave International Handbook of Healthcare Policy and Governance. Basingstoke: Palgrave Macmillan.

Hicks, Alexander. 1999. Social Democracy and Welfare Capitalism: A Century of Income Security Politics. Ithaca: Cornell University Press.

Holahan, John, Alan Weil, and Joshua M Wiener, eds. 2003. Federalism and Health Policy. Washington DC: Urban Institute.

Hooghe, L., and G. Marks. 2015. A Postfunctionalist theory of governance, Vol. I: Measuring regional authority. New York: Oxford University Press.

Huber, Evelyne, Charles Ragin, and John D Stephens. 1993. "Social Democracy, Christian Democracy, Constitutional Structure, and the Welfare State." American Journal of Sociology 99 (3):711-749.

Huber, Evelyne, and John D Stephens. 2001. Development and Crisis of the Welfare State: Parties and Policies in Global Markets. Chicago: University of Chicago Press.

Hwang, Ann, Joshua M Sharfstein, and Christopher F Koller. 2015. "State Leadership in Health Care Transformation: Red and Blue." JAMA 314 (4):349-350.

Immergut, Ellen M. 1992. Health politics: interests and institutions in Western Europe. Cambridge: Cambridge University Press.

Jacobs, Lawrence R, and Timothy Callaghan. 2013. "Why states expand Medicaid: Party, resources, and history." Journal of health politics, policy and law 38 (5):1023-1050.

Jarman, Holly. 2014. The Politics of Trade and Tobacco Control. Basingstoke: PalgraveMacmillan.

Jasanoff, S. 2004a. States of Knowledge: The Co-production of Science and Social Order: Routledge.

Jasanoff, Sheila. 2004b. "The idiom of co-production." In States of knowledge: the coproduction of science and the social order, edited by Sheila Jasanoff, 1-12. Abingdon: Routledge.

Jones, David K. 2013. "Politiques de Sante: The Regional Centralization of French Health Policy." In Decentralization and Federalism in European Health and 
Social Care, edited by Joan Costa i Font and Scott L Greer, 208-227.

Basingstoke: Palgrave.

Jones, David K, Katharine W. V. Bradley, and J B Oberlander. 2013. "Pascal's Wager:

Health Insurance Exchanges, Obamacare, and the Republican Dilemma."

Journal of Health Politics, Policy and Law 39 (1):97-137.

Jones, David K, Phillip M Singer, and John Z Ayanian. 2014. "The Changing Landscape of Medicaid: Practical and Political Considerations for Expansion." JAMA: Journal of the American Medical Association 311 (19):1965-1966.

Kelly, Nathan J., and Christopher Witko. 2012. "Federalism and American Inequality." The Journal of Politics 74 (02):414-426. doi: doi:10.1017/S0022381611001678.

Koivusalo, Meri. 2015. "Health Systems and Policy Space for Health in the Context of European Union Trade Policies." In Services of General Interest Beyond the Single Market, 371-396. Springer.

Kurzer, Paulette. 2012. "Non-communicable diseases: Europe declares war on "fat"." In European Union Public Health Policies: Regional and Global Perspectives, edited by Scott L Greer and Paulette Kurzer. Abingdon: Routledge.

Lazar, H., J.N. Lavis, P.G. Forest, and J. Church. 2013. Paradigm Freeze: Why It Is So Hard to Reform Health-Care Policy in Canada: McGill-Queen's University Press.

Lemieux, Vincent. 2001. Décentralisation, politiques publiques, et relations de pouvoir. Montreal: Presses de l'Université de Montreal.

Lieberman, Robert C, and John S Lapinski. 2001. "American federalism, race and the administration of welfare." British Journal of Political Science 31 (2):303-329.

Lijphart, Arend. 1999. Patterns of Democracy: Government Forms and Performance in Thirty-Six Countries. New Haven: Yale University Press.

Lillvis, Denise F, Anna Kirkland, and Anna Frick. 2014. "Power and Persuasion in the Vaccine Debates: An Analysis of Political Efforts and Outcomes in the United States, 1998 - 2012." Milbank Quarterly 92 (3):475-508.

Loughlin, J., F. Hendriks, and A. Lidström. 2011. The Oxford handbook of local and regional democracy in Europe: Oxford Univ Pr.

Lowery, David, Virginia Gray, and Frank R Baumgartner. 2010. "Policy attention in state and nation: Is anyone listening to the laboratories of democracy?" Publius: The Journal of Federalism:pjq039.

Lynch, Julia. 2017. "Reframing inequality? The health inequalities turn as a dangerous frame shift." Journal of Public Health.

Maioni, Antonia. 1998. Parting at the Crossroads: The Emergence of Health Insurance in the United States and Canada. Princeton: Princeton University Press.

Marchildon, G.P., and K. O'Fee. 2007. Health Care in Saskatchewan: An Analytical Profile: Canadian Plains Research Center.

Marchildon, G.P., and R. Torgerson. 2013. Nunavut: A Health System Profile: MQUP. Martin, Erika G, Patricia Strach, and Bruce R Schackman. 2013. "The State (s) of Health: Federalism and the Implementation of Health Reform in the Context of HIV Care." Public Administration Review 73 (s1):S94-S103. 
Mätzke, Margitta. 2013. "Federalism and Decentralization in German Health and Social Care Policy." In Federalism and Decentralization in European Health and Social Care, edited by Joan Costa i Font and Scott L Greer, 190-207. Palgrave Macmillan.

Mätzke, Margitta, and Harald Stöger. 2015. "Austria." In Comparative Health Care Federalism, edited by Katherine Fierlbeck and Howard A Palley, 15-29. Farnham: Ashgate.

McCann, Pamela J. Clouser. 2015. "The Strategic Use of Congressional Intergovernmental Delegation." The Journal of Politics 77 (3):620-634. doi: $10.1086 / 681057$.

McEwen, Nicola, and Luis Moreno, eds. 2005. The Territorial Politics of Welfare. London: Routledge.

Miller, Edward Alan. 2004. "Advancing Comparative State Policy Research: Toward Conceptual Integration and Methodological Expansion." State and Local Government Review 36 (1):35-58.

Mills, Anne, J Patrick Vaughan, Duane L Smith, and Iraj Tabibzadeh. 1990. "Health system decentralization: concepts, issues and country experience."

Moynihan, Donald P., Pamela Herd, and Elizabeth Ribgy. 2013. "Policymaking by Other Means: Do States Use Administrative Barriers to Limit Access to Medicaid?" Administration \& Society. doi: 10.1177/0095399713503540.

Obinger, Herbert, Stephan Leibfried, and Francis G Castles, eds. 2005. Federalism and the Welfare State: New World and European Experiences. Cambridge: Cambridge University Press.

Okma, Kieke, and Theodore R. Marmor. 2015. "The United States." In Comparative Health Care Federalism, edited by Katherine Fierlbeck and Howard A Palley. Farnham: Ashgate.

Palley, Howard A, and Katherine Fierlbeck. 2015. "Conclusion." In Comparative Health Care Federalism, edited by Katherine Fierbeck and Howard A Palley, 213-226. Farnham: Ashgate.

Peckham, Stephen, Mark Exworthy, Martin Powell, and Ian Greener. 2007. "Decentralizing Health Services in the UK: A New Conceptual Framework." Public Administration 86 (2):559-580.

Rondinelli, D A. 1981. "Government decentralization in comparative theory and practice in developing countries." International Review of Administrative Sciences 47:133-145.

Rondinelli, D A. 1983. "Decentralization in Developing Countries." World Bank Staff Working Papers (581).

Saltman, Richard B. 2008. "Decentralization, re-centralization and future European health policy." The European Journal of Public Health 18 (2):104-106.

Saltman, Richard B, Vaida Bankauskaite, and Karsten Vrangbaek, eds. 2007. Decentralization in Health Care. Maidenhead: McGraw-Hill/ Open University Press.

Shipan, Charles R, and Craig Volden. 2006. "Bottom - up Federalism: the diffusion of antismoking policies from US cities to states." American journal of political science 50 (4):825-843. 
Shipan, Charles R, and Craig Volden. 2008. "The mechanisms of policy diffusion." American journal of political science 52 (4):840-857.

Snyder, Richard. 2001. "Scaling Down: The Subnational Comparative Method." Studies in Comparative International Development 36 (1):93-110.

Stepan, Alfred, and Juan J. Linz. 2011. "Comparative Perspectives on Inequality and the Quality of Democracy in the United States." Perspectives on Politics 9 (04):841-856. doi: doi:10.1017/S1537592711003756.

Thompson, Frank J. 2012. Medicaid Politics: Federalism, Policy Durability and Health Reform. Washington: Georgetown University Press.

Tuohy, Carloyn H. 1999. Accidental Logics: The Dynamics of Change in the Health Care Arena in the United States, Britain, and Canada. Oxford: Oxford University Press.

Webster, Charles. 1990. "Conflict and consensus: explaining the British health service." Twentieth Century British History 1 (2):115-151.

Weissert, W.G., and C.S. Weissert. 2012. Governing Health: The Politics of Health Policy: Johns Hopkins University Press. 